\title{
EFL Learners' Beliefs about Language Learning along Gender, Further Education in Language Institutes \& Different Proficiency Levels
}

\author{
Naemeh Nahavandi \\ Universiti Putra Malaysia \\ Tel: 0060173942723 E-mail: naemeh.nahavandi@gmail.com \\ Jayakaran Mukundan (Corresponding author) \\ Universiti Putra Malaysia \\ Tel: 0060122099717 E-mail: jayakaranmukundan@yahoo.com
}

Received: 01-10-2013

doi:10.7575/aiac.ijalel.v.3n.1p.170
Accepted: 08-11-2013

Published: 01-01-2014

URL: http://dx.doi.org/10.7575/aiac.ijalel.v.3n.1p.170

\begin{abstract}
The aim of the present study was to understand the beliefs of Iranian EFL learners' about language learning. This study was an attempt to understand if there was any relationship between gender, proficiency level and further education in language institutes on beliefs about language learning. Accordingly, 369 EFL engineering students studying in Azad University of Tabriz, Iran were selected based on random sampling. Data were collected using two questionnaires: a demographical questionnaire, and the Beliefs about Language Learning Inventory (BALLI). Data were analyzed using ANOVA, LSD \& t-test. The results of the study showed that the highest mean average among the five components of beliefs about language learning was nature of language learning $(\mathrm{M}=3.91)$, followed by Foreign Language Aptitude $(M=3.85)$, Difficulty of Language Learning $(M=3.42)$, Learning and Communication Strategies $(M=3.35)$ and Motivation and Expectations ( $\mathrm{M}=3.25)$. The findings showed that there was a significant difference between learners' beliefs, gender and further education in language institutes. However, there was not any significant difference between learners' beliefs and their proficiency level. The study concluded with some pedagogical implications.
\end{abstract}

Keywords: Iranian EFL learners, BALLI

\section{Introduction}

Many areas of education are undergoing changes in the way teaching and learning is understood. Teacher centered classes and structural- syllabus teaching are giving way to more student-centered, practical and flexible approaches. In this paradigm shift, the field of second and foreign language teaching is not an exception (Nahavandi, 2011; Nahavandi \& Mukundan, 2012; Nahavandi, 2013; Nahavandi \& Mukundan, 2013c). Generally speaking, interest in language learning and language learners burgeoned in the late 1970s due to the cognitive revolution. The paradigm shift from behaviorism to cognitive science in psychology and education research led to efforts for explaining the cognitive processes in all of the aspects of learning, with language being no exception. Previous studies of language learning put an emphasis on describing externally observable behaviors of language learners, followed by attempts in labeling strategic behaviors and ultimately categorizing those strategic behaviors and linking them to language proficiency.

During the past two decades, there have been various studies concerning beliefs that language learners hold about language learning and many researchers agree with the idea that beliefs play a major role in learner's language success (Dörnyei, 2005; Sakui \& Gaies 1999; Weinert \& Kluwe 1987). For Christison and Krahnke (1986) "studies of learner belief and attitude are valuable sources of insight into language learning" (p.78). Language learners beliefs about learning can be affected by the context in which they learn, which in turn affects their learning behaviors. Horwitz (1987; 1988) did a leading work in examining language learner beliefs about learning a new language. She made an instrument calling it "The Beliefs About Language Learning Inventory (BALLI)". Since then, BALLI has been widely used in different contexts and cultures to evaluate EFL/ESL students' beliefs. For Horwitz (1987, 1988) learners' beliefs about language learning are affected by their previous language learning experiences as well as cultural background. It has also been claimed that beliefs about language learning can be closely linked to the learners' choice of learning strategies (Hosenfeld, 1978; Wenden, 1987a; Yang, 1999). Horwitz (1987a) suggests that understanding language learning beliefs is essential at least for two reasons. The first reason is that these beliefs might influence the expectations that learners have for learning the target language, and the second reason is that such beliefs might be more easily lead to change compared with cognitive style variables or affective variables such as attitude and motivation. To date, no comparative analyses have been conducted, whether university students in Iran with and without further 
education in language institutes differ with each other in terms of their beliefs about language learning. Furthermore as Bernat (2006) states "there is still paucity in literature on the relationship between language learner beliefs and stable individual differences, such as gender" (p. 80). To bridge these gaps, such a comparison study may provide useful information which may in turn encourage more research in this area in Iranian context.

\section{Background of the Study}

\subsection{Beliefs about Language Learning}

For some researchers language learners have certain beliefs about how languages are learned and learners have a conscious knowledge of their mental processes (O'Malley \& Chamot, 1989; Wenden, 1991; Wenden \& Rubin, 1987). Some researchers have differentiated between metacognitive knowledge and beliefs. According to Alexander and Dochy (1995) beliefs are idiosyncratic, subjective and value related. For some other researchers (e.g., Horwitz, 1987; Omaggio, 1978; Wenden,1987a) beliefs about language learning include learners' notions, ideas ,concepts, opinions, assumptions, or mini-theories of the nature of language or language learning. There is a consensus among researchers that individual language learners have different beliefs about how languages are learned. Individual beliefs about language learning may consciously or unconsciously affect learners' approaches to or behaviors in language learning. As an example, learners who put more importance on learning grammar will focus on learning the structure of a sentence or the patterns of a language in formal language learning. In late 1980s, Horwitz's (1985, 1987, \& 1988) research on learners' beliefs made a great contribution to the research of beliefs about language learning. As the first researcher, she systematically assessed learners' beliefs using instruments based on scaled systems. For Horwitz (1999), by understanding learners' beliefs we can better understand learner' approaches to language learning, and learners' use of learning strategies which in turn enables us to appropriately plan language instruction.

\subsection{Studies on Beliefs in EFL Contexts}

There have been plenty of studies on beliefs in EFL context such as China (Zhang and Cui, 2010), Hungary (Rieger, 2009), Iran (Bagherzadeh, 2012; Ghabanchi \& Naji Meidani, 2012; Jafari \& Shokrpour, 2012; Mesri, 2012), Korea (Park, 1995), Lebanon (Diab, 2000, 2006), Malaysia (Nikitina \& Furuoka, 2006), Thailand (Fujiwara, 2011), Turkey (Atlan, 2006; Buyukyazi, 2010; Kunt ,1997; Oz, 2007). Only the results of studies related to the scope of the present study have been discussed here.

In one study, 248 foreign language major students in Turkey were surveyed about their language learning beliefs. The results of the study showed that subjects held a range of beliefs with varying degrees of validity (Atlan, 2006). In another Turkish context, Kunt (1997) studied the beliefs about language learning and language anxiety and the relationship between beliefs and anxiety. BALLI was given to 882 Turkish-speaking university students learning English as a foreign language at two pre-university English programs in North Cyprus. The results of factor analysis identified three categories of beliefs of the Turkish students based on the value and nature of learning English, selfefficacy/ confidence in speaking, and beliefs about social interaction. Furthermore, the results of the study showed high instrumental motivation for learning English for both groups, strong beliefs in the importance of learning English, and high value placed on guessing and repeating during practice.

In Lebanese context, Diab's (2000) used a modified version of BALLI for 284 Lebanese university students learning English and French as foreign languages at three universities in Lebanon. Factor analyses of the results identified four categories of beliefs for each language group. English language students beliefs' included the following: integrative motivation, difficulty of speaking and learning English, the importance of accuracy in speaking English, and the importance of English in Lebanon. For French language students, beliefs included: motivation/ confidence in speaking French, the nature of learning French, the importance of French in Lebanon, and the importance of accuracy in speaking French. A variety of beliefs about foreign languages, were reported by the participants indicating that learning a foreign language seems to be related to the political and socio-cultural context of foreign language education in Lebanon. For Diab (2000), the differences observed in a comparison of the students' beliefs about learning English and their beliefs about learning French might be the result of variation in a particular group's beliefs about learning a different target language.

In Chinese context, Zhang and Cui (2010) studied learning beliefs of 90 distance learners in a 3-year undergraduate English program in China. The results of their study showed that the major difficulty in distance learning for many participants was the paucity of communication with teachers and peers. Furthermore, the results showed that anxiety and frustration in the distance language learners lessened as they considered more advantages in the autonomous method of learning.

In Iranian context, Bagherzadeh (2012) studied language learning beliefs of 125 non-English majors with different levels of English language proficiency on language learning. The results of her study showed that proficiency level had a significant effect on the motivation of students. The more proficient participants reported holding strong beliefs in the category of "motivation and expectations". Furthermore, no significant difference was observed between male and female non-English majors' beliefs in English language learning. In another study Jafari \& Shokrpor (2012) surveyed 80 Iranian ESP learners' beliefs about language learning. The results of their study showed that the highest mean average among the five components of beliefs about language learning was belief of motivations and expectations followed by belief of learning and communication strategies and belief of difficulty of language learning. Moreover, there was a significant difference between learners' beliefs and gender. In the other study, Mesri (2012) surveyed the relationship 
between beliefs about language learning and gender among 90 Iranian EFL learners. The results of her study showed that that there was no significant effect of gender on Iranian university learners' beliefs in learning English.

\subsection{Current Status of English in Iran}

Due to today's growing science and technology all over the world, learning English language has been given much more importance compared to past years, and it is not an exception in Iranian context (Nahavandi \& Mukundan, 2013a). Nevertheless, teaching English in Iran has been difficult both for EFL learners and teachers due to lack of resources and little contact with the target language outside the classroom compared to other EFL learners in other contexts. (Sadeghi, 2005). There are very few English programs broadcasted on TV or radio. Of course, because of advancements in technology and the more frequent use of the Internet, satellite, and rapid growth of private language institutes in Iran, the opportunities for English language learning have greatly improved (Talebinezhad \& Aliakbari, 2002). Furthermore, increasing the number of language institutes can confirm the increase in value and importance that is given to English language in Iran (Nahavandi \& Mukundan, 2013b). In the Iranian curriculum, English language is one of the compulsory subjects. English language is a foreign language in Iran and students are officially taught English from the first year of the guidance school. Thus, Iranian students have to study English for nearly seven years. Three years in Guidance school, three years in Secondary school and one year in Pre-University level. Furthermore, those students who study non-English Majors in universities study English in maximum of 6 credits. They study 3 credits of general English instruction and 3 credits of ESP in which the focus is on their field, related English texts and related terminology. Nevertheless, after learning English for almost 7 years in school and one more year at university, Iranian EFL learners' are not proficient enough in learning English language. The education they receive neither enables the students to attain full competence in using the English language nor helps them to interact with confidence (Nahavandi \& Mukundan, 2013a \& b).

\section{The Study}

In general, the main purpose of the present study was to understand the beliefs of Iranian EFL learners about language learning. The second goal was to understand if there were any differences between students with or without further education in language institutes in terms of their beliefs about language learning. The final goal of the study was to understand the influence of other variables such as gender and self-rated proficiency level on learners' beliefs about language learning.

\subsection{Research Questions}

Based on the objectives of the study the following research questions were raised:

1) What are the beliefs of Iranian EFL learners? Are there any similarities or differences in beliefs about language learning among them?

2) Is there a significant difference between gender and belief?

3) Is there a significant difference between self-rated proficiency level and belief?

4) What are the similarities or differences between those with or without further education in language institutes in their beliefs about language learning?

\subsection{Research Design}

This survey study was conducted on 403 Iranian EFL learners in Azad University of Tabriz, Iran. A demographical questionnaire together with (BALLI), Beliefs about Language Learning Inventory were administered to the selected respondents.

\subsection{Participants}

The participants were 403 Iranian EFL learners in Azad University in Tabriz, Iran during the academic year of 2013. A demographical questionnaire together with (BALLI), Beliefs about Language Learning Inventory was administered to the selected respondents in general English classes in the engineering department. The age range of participants was from 18-41with the average mean of 19.04. From 403 questionnaires only 369 complete questionnaires were fed into SPSS for analysis and other 34 distorted and incomplete questionnaires were discarded.

\subsubsection{Demographic background of the participants}

From whole 369 respondents 173 (46.9) were students without further education in language institutes and other 196 (53.1) were students with further education in language institutes. Considering their gender, 213 were male (57.7) and 156 were female (42.3) students. Considering their self-rated proficiency level, 106 (28.7) were beginners, 209 (56.6) were intermediate and the rest 54 (14.6) were advanced students.

\subsection{Instrumentation}

In order to collect the data, a demographical questionnaire along with Horwitz's (1987) Beliefs about Language Learning Inventory (BALLI, ESL/EFL version) were administered to the selected respondents.

\subsubsection{BALLI}

BALLI includes 36 items in which 33 items are scored on a five-point Likert scale: 1=strongly disagree, $2=$ disagree, $3=$ neither agree nor disagree, $4=$ agree, $5=$ strongly agree. Two items have different response scales $(4$ and 15$)$. Item 4 asks about the perceived degree of difficulty of the English language \& Item 15 asks about the amount of time needed 
for learning a language. The items of BALLI assess learners' beliefs in five areas namely as 1) the difficulty of language learning (six items), defined as the difficulty of learning a foreign language, 2) foreign language aptitude (nine items) defined as special ability for language learning and beliefs about the characteristics of successful language learners, 3) the nature of language learning (six items), defined as relevant issues related to the nature of language learning process, 4) learning and communication strategies (eight items) defined as various strategies learners use to master a second or foreign language, and 5) motivation and expectations (five items) defined as the desire and expectation for language learning opportunities. As BALLI identifies learners' perceptions about language learning, it does not produce a total composite score for the whole instrument. Therefore, the responses to individual items are treated separately. Studies on the BALLI ESL/EFL version have reported reliability of .59 to .71 .

Since the participants were all EFL students in different proficiency levels, the given questionnaires were translated to Persian language in order to prevent any misunderstanding. First, the translated questionnaires were checked by a Persian language lecturer in Tabriz Azad University to make sure that the items retained their meaning and that the translated versions were easily understood. Then, they were back translated into English by a second Persian lecturer to test for inaccuracies and ambiguities. In case of any inconsistencies in translated English version, both lecturers were consulted. In order to ascertain the reliability of the items, a pilot study was carried out with 38 pre-intermediate students at Jahad-e -Daneshgahi institute. After checking the reliability, the translated questionnaires were administered and the respondents were given 30 minutes to answer the questions. The researcher herself was present in data collection procedure, therefore in case of any ambiguity or problem in understanding the questionnaire items assistance and guidance was provided. It is worth mentioning that permission to distribute the questionnaires was obtained from the dean of engineering faculty in Azad University. Respondents were informed that the information they gave would be used only for research purposes, and there was no need for them to write their names on the questionnaire.

\subsection{Procedure}

First permission to distribute the questionnaires was obtained from the dean of engineering faculty in Azad University. Then, the researcher conducted the survey once the department heads approved the request. In engineering department the number of students in each class ranged from 36 to 42 . All classes were requested to fill up the questionnaires. The researcher herself was present in data collection procedure and the collected data were tallied and subjected to parametric statistical analyses.

\subsection{Method of Analysis}

The students' responses to the questionnaire were analyzed in terms of descriptive and inferential statistics. First, the raw data were fed into the computer and after testing for normality, parametric test was run by the Statistical Package of Social Sciences (SPSS) 20 software. The data were analyzed using MANOVA, LSD and t-test. To ensure the quality of the analysis and interpretations, consultations with statisticians were made.

\section{Results of the Study}

For all variables Minimum, Maximum, Mean, Std. Deviation, Variance, Skewness, and Kurtosis were calculated. To test the normality of data for BALLI one-Sample Kolmogorov-Smirnov Test was used. Based on the obtained significant level $>0.05$, distribution of data was normal for all components of BALLI. Therefore parametric statistics was used.

One-Sample Kolmogorov-Smirnov Test

\begin{tabular}{|c|c|c|c|c|c|c|c|c|}
\hline & \multirow[b]{2}{*}{$\mathrm{N}$} & \multicolumn{2}{|c|}{ Normal Parameters ${ }^{\mathrm{a}, \mathrm{b}}$} & \multicolumn{3}{|c|}{ Most Extreme Differences } & \multirow[b]{2}{*}{$\begin{array}{l}\text { Kolmogorov } \\
\text {-Smirnov Z }\end{array}$} & \multirow[b]{2}{*}{$\begin{array}{c}\text { Asymp. Sig } \\
\text { (2-tailed) }\end{array}$} \\
\hline & & Mean & $\begin{array}{c}\text { Std. } \\
\text { Deviation }\end{array}$ & $\begin{array}{c}\text { Absolut } \\
\mathrm{e}\end{array}$ & Positive & $\begin{array}{c}\text { Negativ } \\
\mathrm{e}\end{array}$ & & \\
\hline $\begin{array}{l}\text { Foreign Language } \\
\text { Aptitude }\end{array}$ & 369 & 3.8516 & .46352 & .086 & .051 & -.086 & 1.320 & .082 \\
\hline $\begin{array}{l}\text { Difficulty of } \\
\text { Language Learning }\end{array}$ & 369 & 3.4182 & .48810 & .103 & .103 & -.087 & 1.476 & .068 \\
\hline $\begin{array}{l}\text { Nature of Language } \\
\text { Learning }\end{array}$ & 369 & 3.9090 & .53470 & .133 & .065 & -.133 & 1.463 & .073 \\
\hline $\begin{array}{l}\text { Learning and } \\
\text { Communication } \\
\text { Strategies }\end{array}$ & 369 & 3.3482 & .45107 & .084 & .056 & -.084 & 1.219 & .085 \\
\hline $\begin{array}{l}\text { Motivation and } \\
\text { Expectations }\end{array}$ & 369 & 3.2477 & .50465 & .118 & .118 & -.080 & 1.589 & .064 \\
\hline BALLI & 369 & 3.5858 & .32167 & .084 & .050 & -.084 & 1.561 & .066 \\
\hline
\end{tabular}

a. Test distribution is Normal.

b. Calculated from data.

\subsection{Descriptive Statistics for all five Components of Beliefs}

The results of the study showed that the highest mean average among the five components of beliefs about language learning was nature of language learning $(\mathrm{M}=3.91)$, followed by Foreign Language Aptitude $(\mathrm{M}=3.85)$, Difficulty of 
Language Learning $(\mathrm{M}=3.42)$, Learning and Communication Strategies $(\mathrm{M}=3.35)$ and Motivation and Expectations $(\mathrm{M}=3.25)$. See table 1 for more information.

\begin{tabular}{|c|c|c|c|c|c|c|c|c|c|}
\hline \multicolumn{10}{|c|}{ Descriptive Statistics } \\
\hline & $\mathrm{N}$ & $\begin{array}{c}\text { Minimu } \\
\mathrm{m}\end{array}$ & $\begin{array}{c}\text { Maximu } \\
\mathrm{m}\end{array}$ & Mean & $\begin{array}{c}\text { Std. } \\
\text { Deviation } \\
\end{array}$ & Ske & vness & Kur & tosis \\
\hline & Statistic & Statistic & Statistic & Statistic & Statistic & Statistic & $\begin{array}{c}\text { Std. } \\
\text { Error }\end{array}$ & Statistic & $\begin{array}{c}\text { Std. } \\
\text { Error }\end{array}$ \\
\hline $\begin{array}{l}\text { Foreign Language } \\
\text { Aptitude }\end{array}$ & 369 & 2.89 & 4.89 & 3.85 & .46 & -0.20 & 0.13 & -0.43 & 0.25 \\
\hline $\begin{array}{l}\text { Difficulty of Language } \\
\text { Learning }\end{array}$ & 369 & 2.17 & 4.83 & 3.42 & 0.49 & -0.01 & 0.13 & 0.16 & 0.25 \\
\hline $\begin{array}{l}\text { Nature of Language } \\
\text { Learning }\end{array}$ & 369 & 2.57 & 5.00 & 3.91 & 0.53 & -0.66 & 0.13 & -0.05 & 0.25 \\
\hline $\begin{array}{l}\text { Learning and } \\
\text { Communication } \\
\text { Strategies }\end{array}$ & 369 & 2.13 & 4.50 & 3.35 & 0.45 & -0.09 & 0.13 & -0.15 & 0.25 \\
\hline $\begin{array}{l}\text { Motivation and } \\
\text { Expectations }\end{array}$ & 369 & 2.20 & 4.40 & 3.25 & 0.50 & 0.04 & 0.13 & -0.40 & 0.25 \\
\hline BALLI & 369 & 2.83 & 4.31 & 3.59 & 0.32 & -0.47 & 0.13 & 0.09 & 0.25 \\
\hline
\end{tabular}

\subsection{Comparing Components of Beliefs through t-test}

To understand amount of beliefs in language learning Independent t-test was used with the test value of 3 as the scores vary in the range of 1 to 5 . The results of t-test showed that all five components of beliefs are significantly higher than average. Means are higher than 3, and significant level is $<0.05$.

Independent t-test

\begin{tabular}{lllll}
\hline & $\mathrm{N}$ & Mean & Std. Deviation & Std. Error Mean \\
\hline Foreign Language Aptitude & 369 & 3.85 & 0.46 & 0.02 \\
Difficulty of Language Learning & 369 & 3.42 & 0.49 & 0.03 \\
Nature of Language Learning & 369 & 3.91 & 0.53 & 0.03 \\
Learning and Communication & 369 & 3.35 & 0.45 & 0.02 \\
Strategies & & & & 0.03 \\
Motivation and Expectations & 369 & 3.25 & 0.50 & 0.02 \\
BALLI & 369 & 3.59 & 0.32 & \\
\hline
\end{tabular}

One-Sample Test

\begin{tabular}{|c|c|c|c|c|c|c|}
\hline & \multicolumn{6}{|c|}{ Test Value $=3$} \\
\hline & \multirow[b]{2}{*}{$\mathrm{t}$} & \multirow[b]{2}{*}{$\mathrm{df}$} & \multirow[b]{2}{*}{ Sig. (2-tailed) } & \multirow[b]{2}{*}{ Mean Difference } & \multicolumn{2}{|c|}{$\begin{array}{l}\text { 95\% Confidence Interval of the } \\
\text { Difference }\end{array}$} \\
\hline & & & & & Lower & Upper \\
\hline Foreign Language Aptitude & 35.290 & 368 & .000 & .852 & .8041 & .8990 \\
\hline $\begin{array}{l}\text { Difficulty of Language } \\
\text { Learning }\end{array}$ & 16.460 & 368 & .000 & .418 & .3683 & .4682 \\
\hline Nature of Language Learning & 32.657 & 368 & .000 & .909 & .8543 & .9638 \\
\hline $\begin{array}{l}\text { Learning and } \\
\text { Communication Strategies }\end{array}$ & 14.830 & 368 & .000 & .348 & .3021 & .3944 \\
\hline Motivation and Expectations & 9.428 & 368 & .000 & .248 & .1960 & .2994 \\
\hline BALLI & 34.985 & 368 & .000 & .586 & .5529 & .6188 \\
\hline
\end{tabular}


To rank amount of beliefs Friedman Test was used. The mean and mean of all ranks of variables were calculated. The variable which has the lowest use will have the lowest rank. Based on the results, Chi-square $=499 / 98$, $\mathrm{df}=4$, and level of significance is 0.000 . As level of sig is $<0.05$, it can be concluded that there is a significant difference between mean of variable ranks. Means of Beliefs from lowest to highest are as follows: Motivation \& Expectations, Learning \& Communication strategies, Difficulty of language learning, Foreign language Aptitude, and Nature of Language learning.

Friedman Test

\begin{tabular}{|c|c|c|c|c|c|c|}
\hline & $\mathrm{N}$ & Mean & Mean Rank & Chi-square & df & Asymp. Sig. \\
\hline Foreign Language Aptitude & 369 & 3.85 & 3.98 & 499.983 & 4 & .000 \\
\hline Difficulty of Language Learning & 369 & 3.42 & 2.50 & & & \\
\hline Nature of Language Learning & 369 & 3.91 & 4.00 & & & \\
\hline Learning and Communication Strategies & 369 & 3.35 & 2.43 & & & \\
\hline Motivation and Expectations & 369 & 3.25 & 2.09 & & & \\
\hline
\end{tabular}

\subsection{Comparing beliefs based on gender \& self-rated proficiency level}

To compare beliefs with gender \& self-rated proficiency level, MANOVA was used. Gender was analyzed in two levels and proficiency in three levels of elementary, intermediate and advanced through Wilks' Lambda approach. The results of the study showed that the effect of gender is significant $(\mathrm{sig}<0.05)$ meaning, there is a significant difference between male and female students in their beliefs. Furthermore, the effect of proficiency level is significant as well (sig $<0.05$ ), meaning there is a significant difference between students' levels of proficiency and their beliefs. The interaction between gender and level is not significant. Only there is a significant difference between male \& female students in the component of Learning and Communication Strategies ( $\mathrm{sig}<0.05$ ). Considering other 4 components, there is not a significant difference between male and female students.

Considering the learners' proficiency level, there is not a significant difference between components of Foreign Language Aptitude, Motivation \& Expectations and levels. However, there is a significant difference between Difficulty of Language Learning ، Nature of Language Learning and Communication Strategies \& learners' proficiency level (sig $<0.05)$. The mutual interaction between gender \& proficiency level is not significant in any of the components of beliefs $(\operatorname{sig}>0.05)$.

Descriptive Statistics

\begin{tabular}{|c|c|c|c|c|c|c|c|c|c|c|}
\hline & & Gender & & & & & & & & \\
\hline & & & Male & & female & & & Total & & \\
\hline & $\begin{array}{r}\text { proficiency } \\
\text { level }\end{array}$ & Mean & $\begin{array}{c}\text { Std. } \\
\text { Deviation }\end{array}$ & $\mathrm{N}$ & Mean & $\begin{array}{c}\text { Std. } \\
\text { Deviation }\end{array}$ & $\mathrm{N}$ & Mean & $\begin{array}{c}\text { Std. } \\
\text { Deviation }\end{array}$ & $\mathrm{N}$ \\
\hline \multirow{4}{*}{$\begin{array}{l}\text { Foreign Language } \\
\text { Aptitude }\end{array}$} & Beginning & 3.8732 & .42892 & 78 & 3.6865 & .45868 & 28 & 3.8239 & .44255 & 106 \\
\hline & Intermediate & 3.9413 & .43352 & 106 & 3.7907 & .49307 & 103 & 3.8671 & .46881 & 209 \\
\hline & Advanced & 3.8391 & .47382 & 29 & 3.8533 & .51492 & 25 & 3.8457 & .48859 & 54 \\
\hline & Total & 3.9025 & .43723 & 213 & 3.7821 & .49011 & 156 & 3.8516 & .46352 & 369 \\
\hline \multirow{4}{*}{$\begin{array}{l}\text { Difficulty of } \\
\text { Language Learning }\end{array}$} & Beginning & 3.2842 & .43487 & 78 & 3.1845 & .41658 & 28 & 3.2579 & .43041 & 106 \\
\hline & Intermediate & 3.4528 & .44350 & 106 & 3.4903 & .51546 & 103 & 3.4713 & .47952 & 209 \\
\hline & Advanced & 3.5287 & .58937 & 29 & 3.5267 & .52854 & 25 & 3.5278 & .55679 & 54 \\
\hline & Total & 3.4014 & .46966 & 213 & 3.4412 & .51285 & 156 & 3.4182 & .48810 & 369 \\
\hline \multirow{4}{*}{$\begin{array}{l}\text { Nature of } \\
\text { Language Learning }\end{array}$} & Beginning & 3.7802 & .53635 & 78 & 3.7959 & .63344 & 28 & 3.7844 & .56052 & 106 \\
\hline & Intermediate & 3.9070 & .51112 & 106 & 4.0000 & .51818 & 103 & 3.9528 & .51548 & 209 \\
\hline & Advanced & 3.9507 & .53626 & 29 & 4.0229 & .51948 & 25 & 3.9841 & .52483 & 54 \\
\hline & Total & 3.8665 & .52572 & 213 & 3.9670 & .54304 & 156 & 3.9090 & .53470 & 369 \\
\hline \multirow{4}{*}{$\begin{array}{l}\text { Learning and } \\
\text { Communication } \\
\text { Strategies }\end{array}$} & Beginning & 3.3446 & .41295 & 78 & 3.5893 & .49048 & 28 & 3.4092 & .44572 & 106 \\
\hline & Intermediate & 3.2465 & .38786 & 106 & 3.4830 & .44764 & 103 & 3.3630 & .43389 & 209 \\
\hline & Advanced & 3.0948 & .48603 & 29 & 3.2600 & .48937 & 25 & 3.1713 & .49005 & 54 \\
\hline & Total & 3.2617 & .41725 & 213 & 3.4663 & .46972 & 156 & 3.3482 & .45107 & 369 \\
\hline \multirow{4}{*}{$\begin{array}{l}\text { Motivation and } \\
\text { Expectations }\end{array}$} & Beginning & 3.2077 & .51818 & 78 & 3.3571 & .50584 & 28 & 3.2472 & .51680 & 106 \\
\hline & Intermediate & 3.3094 & .52672 & 106 & 3.2252 & .49759 & 103 & 3.2679 & .51308 & 209 \\
\hline & Advanced & 3.0966 & .41618 & 29 & 3.2560 & .47089 & 25 & 3.1704 & .44537 & 54 \\
\hline & Total & 3.2432 & .51323 & 213 & 3.2538 & .49427 & 156 & 3.2477 & .50465 & 369 \\
\hline
\end{tabular}




\begin{tabular}{rrrrrrrr}
\hline & Effect & Value & F & Hypothesis df & Error df & Sig. & Partial Eta Squared \\
\hline Gender & Wilks' Lambda & .927 & $5.675^{\text {a }}$ & 5.000 & 359.000 & .000 & .073 \\
\hline p.level & Wilks' Lambda & .888 & $4.375^{\text {a }}$ & 10.000 & 718.000 & .000 & .057 \\
\hline Gender $^{*}$ p.level & Wilks' Lambda & .971 & $1.062^{\mathrm{a}}$ & 10.000 & 718.000 & .389 & .015 \\
\hline
\end{tabular}

\begin{tabular}{|c|c|c|c|c|c|c|c|}
\hline Source & Dependent Variable & $\begin{array}{c}\text { Type III Sum of } \\
\text { Squares }\end{array}$ & df & $\begin{array}{l}\text { Mean } \\
\text { Square }\end{array}$ & $\mathrm{F}$ & Sig. & $\begin{array}{c}\text { Partial Eta } \\
\text { Squared }\end{array}$ \\
\hline \multirow[t]{5}{*}{ Gender } & Foreign Language Aptitude & .734 & 1 & .734 & 3.459 & .064 & .009 \\
\hline & $\begin{array}{l}\text { Difficulty of Language } \\
\text { Learning }\end{array}$ & .029 & 1 & .029 & .126 & .722 & .000 \\
\hline & Nature of Language Learning & .230 & 1 & .230 & .816 & .367 & .002 \\
\hline & $\begin{array}{l}\text { Learning and } \\
\text { Communication Strategies }\end{array}$ & 2.940 & 1 & 2.940 & 15.641 & .000 & .041 \\
\hline & Motivation and Expectations & .355 & 1 & .355 & 1.399 & .238 & .004 \\
\hline \multirow[t]{5}{*}{ p.level } & Foreign Language Aptitude & .440 & 2 & .220 & 1.036 & .356 & .006 \\
\hline & $\begin{array}{l}\text { Difficulty of Language } \\
\text { Learning }\end{array}$ & 4.014 & 2 & 2.007 & 8.733 & .000 & .046 \\
\hline & Nature of Language Learning & 1.908 & 2 & .954 & 3.385 & .035 & .018 \\
\hline & $\begin{array}{l}\text { Learning and } \\
\text { Communication Strategies }\end{array}$ & 2.737 & 2 & 1.369 & 7.282 & .001 & .039 \\
\hline & Motivation and Expectations & .426 & 2 & .213 & .838 & .433 & .005 \\
\hline \multirow{5}{*}{$\begin{array}{r}\text { Gender } * \\
\text { p.level }\end{array}$} & Foreign Language Aptitude & .367 & 2 & .183 & .864 & .422 & .005 \\
\hline & $\begin{array}{l}\text { Difficulty of Language } \\
\text { Learning }\end{array}$ & .278 & 2 & .139 & .604 & .547 & .003 \\
\hline & Nature of Language Learning & .088 & 2 & .044 & .157 & .855 & .001 \\
\hline & $\begin{array}{l}\text { Learning and } \\
\text { Communication Strategies }\end{array}$ & .063 & 2 & .031 & .166 & .847 & .001 \\
\hline & Motivation and Expectations & 1.164 & 2 & .582 & 2.293 & .102 & .012 \\
\hline
\end{tabular}

Multiple Comparisons LSD

\begin{tabular}{|c|c|c|c|c|c|c|c|}
\hline Dependent Variable & (I) & $\begin{array}{r}\text { proficiency } \\
\text { level }\end{array}$ & $(\mathrm{J})$ & $\begin{array}{r}\text { proficiency } \\
\text { level } \\
\end{array}$ & $\begin{array}{l}\text { Mean Difference } \\
(\mathrm{I}-\mathrm{J})\end{array}$ & $\begin{array}{l}\text { Std. } \\
\text { Error }\end{array}$ & Sig. \\
\hline \multirow{6}{*}{$\begin{array}{l}\text { Difficulty of Language } \\
\text { Learning }\end{array}$} & & \multirow[t]{2}{*}{ Beginning } & & Intermediate & $-.2134^{*}$ & .05717 & .000 \\
\hline & & & & Advanced & $-.2699^{*}$ & .08015 & .001 \\
\hline & \multirow{2}{*}{\multicolumn{2}{|c|}{ Intermediate }} & & Beginning & $.2134^{*}$ & .05717 & .000 \\
\hline & & & & Advanced & -.0565 & .07318 & .441 \\
\hline & \multirow{2}{*}{\multicolumn{2}{|c|}{ Advanced }} & & Beginning & $.2699^{*}$ & .08015 & .001 \\
\hline & & & & Intermediate & .0565 & .07318 & .441 \\
\hline \multirow[t]{6}{*}{ Nature of Language Learning } & \multirow{2}{*}{\multicolumn{2}{|c|}{ Beginning }} & & Intermediate & $-.1685^{*}$ & .06331 & .008 \\
\hline & & & & Advanced & $-.1998^{*}$ & .08877 & .025 \\
\hline & \multirow{2}{*}{\multicolumn{2}{|c|}{ Intermediate }} & & Beginning & $.1685^{*}$ & .06331 & .008 \\
\hline & & & & Advanced & -.0313 & .08105 & .700 \\
\hline & \multirow{2}{*}{\multicolumn{2}{|c|}{ Advanced }} & & Beginning & $.1998^{*}$ & .08877 & .025 \\
\hline & & & & Intermediate & .0313 & .08105 & .700 \\
\hline \multirow{6}{*}{$\begin{array}{l}\text { Learning and Communication } \\
\text { Strategies }\end{array}$} & \multirow{2}{*}{\multicolumn{2}{|c|}{ Beginning }} & & Intermediate & .0462 & .05169 & .372 \\
\hline & & & & Advanced & $.2379^{*}$ & .07248 & .001 \\
\hline & \multirow{2}{*}{\multicolumn{2}{|c|}{ Intermediate }} & & Beginning & -.0462 & .05169 & .372 \\
\hline & & & & Advanced & $.1917^{*}$ & .06618 & .004 \\
\hline & \multirow{2}{*}{\multicolumn{2}{|c|}{ Advanced }} & & Beginning & $-.2379^{*}$ & .07248 & .001 \\
\hline & & & & Intermediate & $-.1917^{*}$ & .06618 & .004 \\
\hline
\end{tabular}

\subsection{Comparing beliefs based on further education versus no education in language institutes}

To compare beliefs between those who had further education in language institutes and those who did not have, MANOVA was used through Wilks' Lambda approach. The results of the study showed that the effect of group is significant ( $\operatorname{sig}<0.05$ ), meaning there is a significant difference between these two groups in their beliefs. On the whole, beliefs among no education students are more than other group. The results of univariate showed that, Foreign 
Language Aptitude \& Difficulty of Language Learning are more among no education group (sig $<0.05$ ). However, there is not a significant difference between these two groups in other 3 components of beliefs $(\operatorname{sig}>0.05)$.

\section{Descriptive Statistics}

\begin{tabular}{|c|c|c|c|c|}
\hline & Group & Mean & Std. Deviation & $\mathrm{N}$ \\
\hline \multirow[t]{3}{*}{ Foreign Language Aptitude } & $\begin{array}{r}\text { No } \\
\text { education }\end{array}$ & 4.0199 & .39059 & 173 \\
\hline & $\begin{array}{r}\text { Further } \\
\text { education }\end{array}$ & 3.7029 & .47282 & 196 \\
\hline & Total & 3.8516 & .46352 & 369 \\
\hline \multirow[t]{3}{*}{ Difficulty of Language Learning } & $\begin{array}{r}\text { No } \\
\text { education } \\
\end{array}$ & 3.4981 & .47037 & 173 \\
\hline & $\begin{array}{r}\text { Further } \\
\text { education }\end{array}$ & 3.3478 & .49377 & 196 \\
\hline & Total & 3.4182 & .48810 & 369 \\
\hline \multirow[t]{3}{*}{ Nature of Language Learning } & $\begin{array}{r}\text { No } \\
\text { education }\end{array}$ & 3.9364 & .47689 & 173 \\
\hline & $\begin{array}{r}\text { Further } \\
\text { education }\end{array}$ & 3.8848 & .58111 & 196 \\
\hline & Total & 3.9090 & .53470 & 369 \\
\hline \multirow[t]{3}{*}{ Strategies } & $\begin{array}{r}\text { No } \\
\text { education }\end{array}$ & 3.3663 & .44534 & 173 \\
\hline & $\begin{array}{r}\text { Further } \\
\text { education }\end{array}$ & 3.3323 & .45662 & 196 \\
\hline & Total & 3.3482 & .45107 & 369 \\
\hline \multirow[t]{3}{*}{ Motivation and Expectations } & $\begin{array}{r}\text { No } \\
\text { education }\end{array}$ & 3.2717 & .48985 & 173 \\
\hline & $\begin{array}{r}\text { Further } \\
\text { education }\end{array}$ & 3.2265 & .51770 & 196 \\
\hline & Total & 3.2477 & .50465 & 369 \\
\hline
\end{tabular}

Multivariate Tests

\begin{tabular}{rrrccccc}
\hline & Effect & Value & F & Hypothesis df & Error df & Sig. & Partial Eta Squared \\
\hline Group & Wilks' Lambda & .862 & $11.666^{\mathrm{a}}$ & 5.000 & 363.000 & .000 & .138 \\
\hline
\end{tabular}

Tests of Between-Subjects Effects

\begin{tabular}{|c|c|c|c|c|c|c|c|}
\hline Source & Dependent Variable & $\begin{array}{c}\text { Type III Sum of } \\
\text { Squares }\end{array}$ & $\mathrm{df}$ & $\begin{array}{l}\text { Mean } \\
\text { Square }\end{array}$ & $\mathrm{F}$ & Sig. & $\begin{array}{l}\text { Partial Eta } \\
\text { Squared }\end{array}$ \\
\hline \multirow[t]{5}{*}{ Group } & Foreign Language Aptitude & 9.232 & 1 & 9.232 & 48.517 & .000 & .117 \\
\hline & Difficulty of Language Learning & 2.075 & 1 & 2.075 & 8.898 & .003 & .024 \\
\hline & Nature of Language Learning & .244 & 1 & .244 & .855 & .356 & .002 \\
\hline & $\begin{array}{l}\text { Learning and Communication } \\
\text { Strategies }\end{array}$ & .107 & 1 & .107 & .523 & .470 & .001 \\
\hline & Motivation and Expectations & .187 & 1 & .187 & .735 & .392 & .002 \\
\hline
\end{tabular}

\section{Discussion}

Regarding the five components of beliefs about language learning, the results of the present study show that students have the strongest belief in nature of language learning $(M=3.91)$, followed by Foreign Language Aptitude $(M=3.85)$, Difficulty of Language Learning $(\mathrm{M}=3.42)$, Learning and Communication Strategies $(\mathrm{M}=3.35)$ and Motivation and Expectations $(\mathrm{M}=3.25)$. However, comparing components of beliefs through t-test revealed that all five components of beliefs are significantly higher than average. Means are higher than 3 , and significant level is $<0.05$, meaning Iranian EFL learners have significant strong beliefs about language learning in all five components. Furthermore, the results show that the effect of gender is significant $(\operatorname{sig}<0.05)$ meaning, there is a significant difference between male and female students in their beliefs. Mean of all components except foreign language aptitude among females are more than their male counterparts. Furthermore, the effect of proficiency level is significant $(\operatorname{sig}<0.05)$, meaning there is a significant difference between students' self-rated proficiency level and their beliefs. The interaction between gender 
and level is not significant. There is a significant difference between male \& female students in the component of Learning and Communication Strategies (sig < 0.05). Considering other 4 components, there is not a significant difference between male and female students. Considering the learners' proficiency level, there is not a significant difference between components of Foreign Language Aptitude, Motivation \& Expectations and levels. However, there is a significant difference between Difficulty of Language Learning ، Nature of Language Learning and Communication Strategies \& learners' proficiency level ( $\mathrm{sig}<0.05)$. The mutual interaction between gender \& proficiency level is not significant in any of the components of beliefs ( $\mathrm{sig}>0.05$ ). The results of the study showed that the effect of group is significant ( $\operatorname{sig}<0.05$ ), meaning there is a significant difference between these two groups (those who had further education in language institutes and those who did not have) in their beliefs. On the whole, beliefs among no education students are more than other group. The results of univariate showed that, Foreign Language Aptitude \& Difficulty of Language Learning are more among no education group (sig $<0.05)$. However, there is not a significant difference between these two groups in other 3 components of beliefs ( $\operatorname{sig}>0.05)$.

Considering the five components of BALLI, the results of the present study contradict with the studies of Sioson (2011), Shen (2006) \& Jafari \& Shokrpour (2012) in which the highest mean score were motivation and expectations. While belief of foreign of language aptitude ranked last. Regarding the effects of gender on learners' beliefs, the results of the present study indicates that gender affects students' belief about learning language. The results revealed that female students were more likely than their male peers to agree that certain approaches were important in language learning. Therefore, the findings of the present study is in line with Bacon and Finnemann's (1992) study in which females were more motivated and more open to authentic input, they also showed more positive attitude towards target language speakers. Furthermore, in Rieger's (2009) study, gender affected a number of beliefs factors that were statistically significant. In Jafari \& Shokrpour's (2012) study, there was a significant difference between male \& female learners as well. However, this finding contradicts with the results of some other studies in which no significant relation between language learners' beliefs and gender was observed (Bagherzadeh, 2012; Bernat and Liyod, 2007; Mesri, 2012; Tercanlioglu, 2005). Regarding the effect of proficiency level, the results are in line with Bagherzadeh's (2012) study in which proficiency level had a significant effect on some components of beliefs.

\section{Conclusion \& Implications of the Study}

The aim of the present study was to understand the beliefs of Iranian EFL learners' about language learning and whether or not gender, proficiency level and further education in language institutes affected learners' beliefs about language learning. The results of the study showed that Iranian EFL learners have got strong beliefs about language learning. The two components of beliefs with the lowest rank were strategies of learning followed by motivation \& expectation. Concerning language learning strategies Oxford (1990) claims that "language learning strategies encourage greater overall self direction" (p. 10). He continues to claim that "self-directed students gradually gain greater confidence, involvement, and proficiency" (p. 10). Therefore it seems that steps might be taken to encourage students to use different learning strategies and to be more self-directed. Concerning Motivation \& expectations Gardner and MacIntyre (1991) claim that motivated students are more active in language classes and tasks and are less likely to drop out of language study in the following years. In addition, Gardner (1985) claims that motivation encourages greater overall effort and results in greater success concerning language proficiency and achievement. As the mean of motivation ranked the least in the present study, it is hoped that improvement in our English teaching system in Iranian context could be obtained, and the motivation of our students could accordingly be increased especially at universities. Therefore, it can be suggested that while presenting teaching materials and information content of the lessons, students' motivation should accordingly be considered. Teachers can assist learners in setting goals for themselves in learning languages and helping them to achieve their goals by giving them feedback, using familiar content or examples of previously learned materials, using praise, having interesting contexts, using simulation and learning games, and being responsive to students' attitudes. Furthermore, classroom atmosphere should be meaningful, purposeful, creative and encouraging (Nahavandi \& Mukundan, 2013 b).

Considering the context of learning, (further education in language institutes versus no education group), Foreign Language Aptitude \& Difficulty of Language Learning are more among no education group. Intuitively, it would seem that language learning among students with further education in language institutes would be different from those of no education in language institutes because of the context they are learning the language. Horwitz (1999) claims that differences in language learning beliefs among the students in the same cultural group exist. Nespor (1987) reports that beliefs can be affected or shaped by personal events, episodes, or experiences. Private language institute students possess certain skills, strategies, understandings or beliefs that may enable them to approach the process of language learning more effectively than those studying in a university. Although the two sample groups in this study share the same first language, differences in beliefs between two groups might exist because of the vastly different educational environments. Research suggests that if teachers want to help their students, they need to begin to expect and to look for differences in their thinking and behaving. Based on this view, the present study tries to provide information on thoughts and behaviors of learners in learning in order to minimize misunderstanding between teachers and students, prevent academic failures of students, and provide valuable information about their beliefs. Based on the results of the study, some pedagogical implications can be obtained. First, by understanding beliefs about language learning held by Iranian EFL learners' teachers and educators can better understand the situation of EFL learners in Iran. Teachers can encourage appropriate beliefs and provide effective instruction based on learners' situation, which in turn can lead to learning and teaching English more effectively. Teachers can increase students' level of motivation in English language classrooms by setting goals for students in learning English, providing students' knowledge regarding language 
learning, and inspiring students to learn. Besides, the increasing number of students studying in private language centers can focus the attention of teachers and researchers to the special needs of the students, especially the need to overcome any academic difficulties arise from educational differences. Furthermore, policy makers can design courses that arouse students' interests, and create curriculum in which students needs and goals are satisfied (Jafari \& Shokrpor 2012). It is hoped that the present research may encourage further research in the area of beliefs among EFL learners by other interested researchers. However, worthy of noting that cautious must be taken while interpreting the results of the present study. This study was conducted with only 369 EFL students. Therefore, when trying to make generalizations of the findings to larger populations in Iran or to other populations with different ethnic, linguistic, or educational backgrounds caution will be required.

\section{References}

Alexander, P. A., \& Dochy, F. J. (1995). Conceptions of knowledge and beliefs: A comparison across varying cultural and educational communities. American Educational Research Journal, 32(2), 413-442.

Altan, M. Z. (2006). Beliefs about Language Learning of Foreign Language-Major University Students. Australian Journal of Teacher Education, 31(2), S. 45-52.

Bagherzadeh, H. (2012). Language learning beliefs of non-English majors: Examining the role of English language proficiency. Journal of Language Teaching and Research, 3(4), 784-792.

Bernat, E. (2006). Assessing EAP learners' beliefs about language learning in the Australian context. Asian EFL Journal, 8(2), 202-227.

Bernat, E., \& Lloyd, M. (2007). Exploring the gender effect on EFL learners' beliefs about language learning. Australian Journal of Educational and Developmental Psychology, 7, 79-91

BÜYÜKYAZI, M. (2010). The Beliefs of University Foreign Language Students and Their Teachers about Language Learning. Sosyal Bilimler, 8(1), 169-182.

Christison, M. A., \& Krahnke, K. J. (1986). Student perceptions of academic language study. TESOL quarterly, 20(1), 61-81.

Diab, R. L. (2000).Political and socio-cultural factors in foreign language education: the case of Lebanon.Texas Papers in Foreign Language Education, 5 (2000), pp. 177-187.

Diab, R. L. (2006). University students' beliefs about learning English and French in Lebanon. System, 34, 80-96.

Dörnyei, Z. (2005). The psychology of the language learner: Individual differences in second language ac-quisition. Mahwah, NJ: Lawrence Erlbaum Associates.

Fujiwara, T. (2011). Language Learning Beliefs of Thai EFL University Students: Dimensional Structure and Cultural Variations. Electronic Journal of Foreign Language Teaching, 8(1), 87-107.

Gardner, R. C. (1985). Social Psychology and Second Language Learning, London: Edvard Arnold.

Gardner, R. C. \& MacIntyre, P. D. (1991). An instrumental motivation in language study: Who says it isn't effective? Studies in Second Language Acquisition, 13, 57-72.

Ghabanchi, Z., \& Meidani, E. N. (2012). Beliefs about language learning and strategy use: the case of Iranian nonEnglish majors. World Journal of English Language, 2(1), p21

Hosenfeld, C. (1978). Learning about learning: Discovering our students' strategies. Foreign Language Annals. 9, $117-$ 129.

Horwitz, E.K. (1987). Surveying student beliefs about language learning. In A.Wenden, \& J. Rubin (Eds.), Learner strategies in language learning. Englewood Cliffs, NJ: Prentice-Hall. (pp.119-129).

Horwitz, E.K. (1988). The beliefs about language learning of beginning university foreign language students. The Modern Language Journal, 72(3), 283-294.

Horwitz, E.K. (1999). Cultural and situational influences on foreign language learners' beliefs about language learning: A review of BALLI studies. System, 27, 557-576.

Jafari, S. M., \& Shokrpour, N. (2012). The Beliefs of Iranian ESP Students about Language Learning. Journal of Educational and Social Research, 157.

Kunt, N. (1997). Anxiety and Beliefs about Language Learning: A study of Turkish speaking university students learning English in North Cyprus. Dissertation Abstracts, International, A: The Humanities and Social Sciences, 59 (1).

Mesri, F. (2012). The Relationship between Gender and Iranian EFL Learners' Foreign Language Classroom Anxiety (FLCA). International Journal of Academic Research in Business and Social Sciences, 2(6), 147-156.

Nahavandi, N. (2011). The effect of task-based activities on EFL learners' reading comprehension. In Mukundan, J., Nimehchisalem, V., Menon, S., Jin, Y.J., Roslim, R., Leong, A., Mohamad, A. \& Philip, A. (Eds.). (2011). ELT Matters 5 (pp.56-69). Petalingjaya, Malaysia: Galaxy. 
Nahavandi, N., \& Mukundan, J. (2012). Task-based Language Teaching from Teachers' Perspective. International Journal of Applied Linguistics \& English Literature, 1(6), 115-121, doi:10.7575/ijalel.v.1n.6p.115.

Nahavandi, N. (2013). Task-based activities in reading comprehension classes: Task-based language teaching \& learning. LAP Lambert Academic Publishing.

Nahavandi , N. \& Mukundan, J. (2013a). Foreign Language Learning Anxiety among Iranian EFL learners Along Gender \& Different Proficiency Levels. Language in India. 13(1), 133-161.

Nahavandi , N. \& Mukundan, J. (2013b). Iranian EFL Engineering Students' Motivational Orientations towards English Language Learning along Gender and Further Education in Language Institutes. International Journal of Linguistics, 5(1), doi:10.5296/ijl.v5i1.2684.

Nahavandi , N. \& Mukundan, J. (2013c). Task-based cycle in reading comprehension classes. International Journal of Applied Linguistics \& English Literature, 1 (6), 115-121, doi:10.7575/aiac.ijalel.v.2n.2p.107.

Nespor, J. (1987). The role of beliefs in the practice of teaching. Journal of Curriculum Studies, 19(4), 317-328.

Nikitina, L., \& Furuoka, F. (2006). Re-examining Horwitz's beliefs about language learning inventory (BALLI) in the Malaysian Context. Electronic Journal of Foreign Language Teaching, 3(2), 209-219.

O'Malley, J. M. and A. U. Chamot (1989). Learning Strategies in Second Language Acquisition. Cambridge University Press, Cambridge.

Omaggio, A.C. (1978). Successful language learners: What do we know about them? ERIC/CLL News Bulletin, May, 23.

Oxford, R. L., Roberta Z. Lavine and David Crookal (1990). Language Learning Strategies: What Every Teacher Should Know. Heinle \& Heinle, Boston.

OZ, H. (2007). Understanding Metacognitive Knowledge of Turkish EFL Students in Secondary Education. NovitasROYAL, 1(2), S. 53-83.

Park, G.,( 1995) . Language learning strategies and beliefs about language learning of university students learning English in Korea. Unpublished Doctoral Dissertation, The University of Texas at Austin, Austin, TX.

Rieger, B. (2009). Hungarian university students' beliefs about language learning: A questionnaire study. WoPaLP, 3 , 97-113.

Sadeghi, A. R. (2005). ESP in Iran: A transition from present state. In: G. R Kiany, and M. Khayyamdar, (Eds.), Proceedings of the First National ESP/EAP Conference, 2, Tehran.

Sakui, K. \& Gaies, S.J. (1999). Investigating Japanese learners' beliefs about language learning. System 27, 473-492.

Shen, M. C. (2006). The relationship between beliefs about language learning and learning strategy use of junior high school students. Unpublished M.A. thesis, Leader University.

Sioson, I, C. (2011). Language Learning Strategies, Beliefs, and Anxiety in Academic Speaking Task, Philippine ESL Journal, 7, 3-27.

Talebinezhad, M. R., \& Aliakbari, M. (2002). Evaluation and justification of a paradigm shift in the current ELT model in Iran. Linguistik online, 10(1), 21-28. Retrieved from www.linguistik-online.de/10_02/talebinezhadaliakbari.pdf

Tercanlioglu, L. (2005). Pre-service EFL teachers' beliefs about foreign language learning and how they relate to gender. Research in Educational Psychology, 53(1), 145-162.

Weinert, F.E. \& Kluwe, R.H. (Eds.) (1987). Metacognition, motivation and understanding. Hillsdale, NJ: Lawrence Erlbaum.

Wenden, A.L., Rubin, J. (Eds.), (1987). Learner Strategies in Language Learning. Prentice-Hall, Englewood Cliffs, NJ. Wenden, A L. (1991). Learner Strategies for Learner Autonomy London Prentice-Hall.

Yang, D. (1999). The relationship between EFL learners' beliefs and learning strategy [Special Issue]. System, 27, 515535 .

Zhang, X. \& Cui, G. (2010). Learning beliefs of distance foreign language learners in China: A survey study. System, 38, 30-40. 